\title{
ICT and Accounting Education. An innovative teaching method: the Practice Enterprise
}

\section{Daniele Gualdi}

School of Economics, Unversity of Bologna, Italy.

\begin{abstract}
The training of future accountants also needs to take into account the changes which have taken place in the accounting profession following profound transformations at economic level. Most of all, however, it should promote a teaching approach which manages to go beyond traditional frontal lectures in order to facilitate active learning. For all these reasons, the various accounting education syllabuses should be integrated with the use of ICT, thus helping achieve skills which are considered fundamental for employment purposes. These include problem solving, decision making, and team working, which is what the literature about accounting education continuously suggests. This paper is dedicated to discussing how all this can become possible through what is known as the Practice Enterprise methodology. The latter allows students to get to know the company by shaping it, as well as to apply accounting disciplines in a proactive and involved manner, making use of the most advanced ICT tools. The intent of this paper is also to show, also through research outcomes, how this method can reshape the teaching of accounting and allow for students' training in an environment where they can apply effectively their theoretical knowledge and thus develop new knowledge, skills and competences.
\end{abstract}

Keywords: Accounting Education; Active Learning; ICT; Pracitice Enterprise. 


\section{Introduction}

There has been much debate in literature about the need to go beyond the traditional way of teaching disciplines related to Accounting Education in Universities, using more innovative methods based on Active Learning. In this regard Osman S.Z.M et al. (2014), among many others, have underscored the importance of involving students in the achievement of results; on the other hand, Prince (2004) has given his own contribution by highlighting the concepts of collaborative and cooperative learning. Active learning and teaching by competences go hand in hand towards outlining a quantum leap in the training of accountants, being aware that the latter cannot merely be based on conventional theoretical backgrounds, but should also be aimed at achieving skills which are considered fundamental for finding a job. These are: team working, problem solving, decision making, critical thinking, communicative skills, autonomy and responsibility. These are actually the indications given by the Dublin Descriptors in December 2004 which have implemented the Bologna Process. At the same time a more active role on the part of the student is acknowledged, and the competences mentioned above can be achieved more effectively by using the new ICT tools. The latter are the drivers of the main changes which are occurring on a world scale. According to Elsadaani (2015), economic development relies on ICT, therefore it is necessary to prepare students for its use in an advanced way throughout the academic pathways followed. The job of accountants itself has changed and diversified, to the extent of being unable to do without new technologies. This study includes a presentation of an active learning method - the Practice Enterprise - where use is widely made of ICT to show hos their use can help renew the teaching of accounting and prepare undergraduates in the best way for changes in the accounting profession.

\section{Theorethical Background}

One of the elements in common between the different approaches followed by authors who have studied this topic is the acknowledgement of how difficult it is for training systems to keep in step with the changes which have taken place in the accounting profession, caused in turn by economic transformations at social level. Albrecht et al. (2000), in a survey conducted in the USA, highlighted the difficulties for traditional lecturing to encourage critical thinking in would-be accountants and to use concrete approaches to apply the theoretical concepts that are being presented. Howieson, (2003) pointed out that "despite the changes underway and those expected in business practice, accounting still seemed to be mostly taught as part of a format which consisted in a long series of lectures, exercises and workshops based on independent topics and associated with technical matters, totally unrelated to other similar disciplines, with little effort being made to establish connections between abstract concepts and what happens in the real world." According to Rhodes (2013), accountants' training has not been adjusted to changes in the profession itself, which is why it needs to be integrated 
with ICT in order to fill this gap. It is the opinion of Baharun et al. (2006) that accounting education needs to be reformulated in order to include competences related to ICT. According to Jebeile et al. (2010), the use of ICT for training accountants can help develop a learning environment which fosters the achievement of important competences such as communication, interpersonal skills, as well as critical and analytical thinking. In the view of Veneziani (2016), it is essential to introduce, as part of the training of accountants, specific courses on ICT, and "to combine the traditional frontal lecture with active methods aimed at developing skills and soft skills". It is the opinion of Wessesls (2007) that the gap between the competences of graduates in accounting and the requirements of the profession is due to the limited use of software packages during their course of studies. One of the purposes of this paper is to prove that it is necessary to go beyond a separate use of these software systems, to make sure that their integration results in a learning environment where the new technologies which are being used allow for sharing information, processing data and making them available to students so that they can apply as effectively as possible their theoretical knowledge, thus developing new knowledge, skills and competences.

\section{The Practice Enterprise (PE) in Accounting Education}

Among the active learning methods in Accounting Education, aimed at promoting the skills which have been outlined in section 1 , those based on simulation seem to be the most effective. The latter range from Business Games to what is known as Practice Enterprise. PE reproduces the actual way of operating of a company in respect of corporate organisation, environment, relations and objectives, presenting the main functions in the company, most notably administration, human resources, sales, with each of the students being assigned a specific job, which is expected to be as close as possible to what happens in the real world. The PE method has become widespread in upper secondary schools and in various Universities at international level. There are currently 7,500 PEs which have joined the Europen-Pen International global network. Managing a virtual enterprise as if it were real, allows for an understanding of how it operates, its organisation, the relation between the various management areas, with a view to using the accounting IT system in a unified manner, fully grasping the logic and purposes of company operations. As part of this innovative simulation space, according to Gualdi et al. (2015), the student is expected to interpret the various events within the company from different perspectives, as well as to take over different roles depending on the performances required, in order to gradually become more aware of their learning process, building knowledge through collaboration processes facilitated by the internet. Moving from the classroom to a workshop, for Veneziani (2012), means going beyond the "talk and chalk" approach to the topics dealt with, thus favouring a new way to learn about accounting. 


\section{The PE organisation and ICT}

In a workshop dedicated to PE, students are called upon to perform the same management tasks as in a real company, from incorporation to company management, including virtual manufacturing and trade in goods and services, possibly until the business is wound up. As part of this experience, according to Bianchi et al. (2014), the student is expected to abide by all legal formalities, mandatory tax and accounting deadlines, to become familiar with paperwork, management software and communication procedures, which are commonly used in a company. All this is done with the indispensable support of ICT. The IT system is actually a pivotal point where management transactions are recorded to produce documents which include statements of accounts, balance sheets and the necessary data for control and planning in the company. The software used is generally the same as in real companies. If company operations are limited to bookkeeping, a dedicated software might be sufficient; on the other hand, as is usually the case, if the idea is to train students in all aspects of accounting, including management control, human resource administration, treasury management and auditing, then specialized software systems are required, each of which will need to be integrated within the company's IT system. Training students through the use of virtual enterprise technologies, results in a quantum leap in terms of learning about them. The use of ICT tools helps make students accountable for entering data in the company's IT system, searching for possible errors, consistencies and correlations, moving towards a learning approach focused on problem solving. Acording to Krishna (2007), students are expected to "use technology as a tool aimed at searching, organising, assessing and communicating information". It is clear that actually managing a company's IT system to produce financial statements is different from knowing about how the latter are drafted; as a matter of fact the process leading to the production of financial statement involves the ability to deal with accounting issues, conduct surveys, make assessments, consider the company as a unified system, and - last but not least - deploy adequate mental flexibility. In each of these phases the exercise of critical knowledge is stimulated, as well as an approach based on seeing the company as a system where all the sectors in which it is organised contribute to defining the results to be achieved. The accountants' training process begins by entering in the IT system the business plan, and a budget for the business period. This is followed by management operations, the latter include purchases, sales, collections, payments, corporate financing, the cost of staff, fiscal transactions, etc... during this phase the student needs to be able to select all relevant paperwork for accountancy, to record them correctly under general and analytical accounting and to regulate them financially, according to the deadlines, as well as meeting mandatory legal requirements. In each lesson the student is called upon to verify the accounting situation and to check in real time that the books are being properly kept, to point out any error, ascertain the consistency of all transactions which have taken place, as well as allow other offices and departments to get the necessary information for their own activities. The reporting 
and auditing activity takes place through a continuous comparison between accounting data and those required for budgeting purposes. The accounting process ends with the drafting of the financial statements, after having calculated the taxes due from the company. As regards using the PE in the Accounting sector, in respect of other departments, reference is made here to research (Benvenuti 2019) carried out on the basis of a questionnaire filled in by 137 students at Bologna University di Bologna, Scuola di Economia, Management e Statistica in Forlì and by the Department of Economics in Parma, who have attended the respective PE courses in the Academic Years 2016/2017, 2017/2018 and 2018/2019. Each student was asked five questions regarding what had been learnt in each office, in respect of knowledge acquired and issues encountered. Each of them could be assigned a score between 1 and 5, based on the relevance of the results which the respondent felt had been achieved.

A comparison between the deviation of survey results in the various deparments and the average values produced the values summarised in fig. 1 .

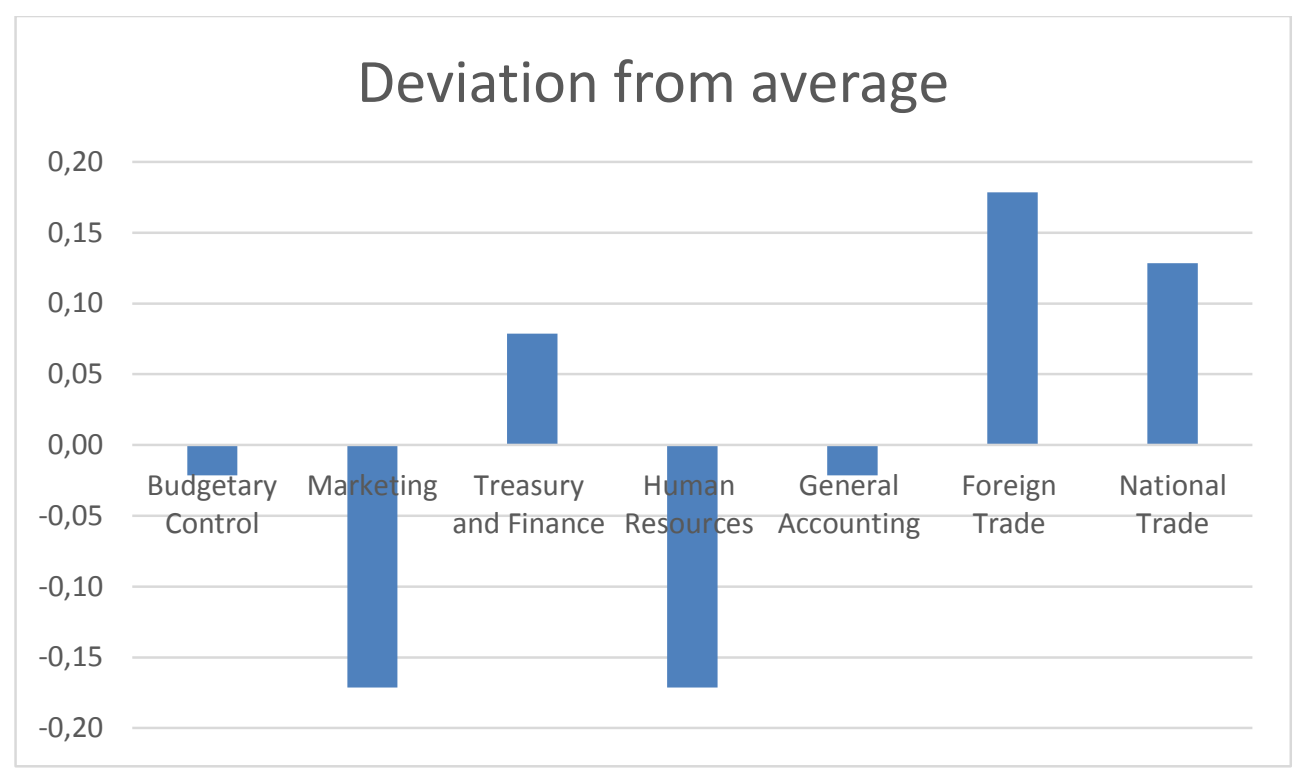

Figure 1. Deviation from average of students' self-assessment of learning outcomes.

It appears that the smallest deviation from average refers to the Accounting, Management Control and Treasury and Finance offices. Marketing and Human Resources show the most negative deviation, while the deviation for Italian and Foreign Trade is positive. Students attending marketing units were mainly involved in designing the company's websitesi, the sales strategy, as well as the products and services to be offered. A theory, confirmed by interviews with participants, is that in departments with the highest deviation values, the objectives assigned to students were not as clear as those in offices supported by a dedicated 
software, specifically Managemetn Control, Treasury and Finance or Accounting. On the other hand, the Italian and Foreign Trades units, with the most substantial positive deviation, share a direct perception of the results of the results of their work through the contact with customers and a positive trend of the market tresponse registered every time products and services are launched (Bianchi 2020).

This theory is confirmed by the answers which students have given in respect of the improvement of their knowledge.

As regards Accounting functions, which are developed in the PE for General Accounting and Management Control students have pointed out the following:

1) General Accounting

At the end of the course, the 25 students who worked in this department have awarded the highest score $(4,4)$ to improving the knowledge of the subject and to more solid preparation $(4,3)$. More specifically, this has been achieved thanks to the use of software $(4,4)$ which has allowed for better understanding of the financial statements $(3,2)$. The increased knowledge and skills have resulted in the ability to assess corporate trends through an evaluation of the accounting situation $(3,5)$; on the other hand, with regard to theoretical knowledge, the learning outcome has involved making it easier to select the most relevant transactions and paperwork from a bookkeeping perspective $(3,8)$.

2) Management Control

a) The self-assessment by the 15 students who worked in this office, has led to concluding that there has been a marked improvement in their knowledge of management control $(4,6)$ and a more solid preparation $(3,8)$. More specifically, this experience was considered useful to establish a clearer relationship between general financial accounting and management control $(3,3)$. The greatest difficulties were encountered in managing dedicated software for management control $(3,5)$, and in connecting financial statements with the budget $(3,4)$. As regards the improvement of their knowledge, this translated into better understanding of the accounting process: general accounting measurement, control, analysis of deviations, redrafting the financial budget $(3,7)$. These results confirm that using in the PE some form of dedicated software for Accounting purposes leads to positive results, altough this is still true only to a limited extent in other corporate departments.

\section{Conclusions}

In this paper an attempt has been made to prove the need that traditional frontal lectures for Accounting Education should be complemented by more proactive methods, based on the 
centrality of the student and better able to achieve the skills which are most sought after on the workplace. At the same time the importance of adding ICT as part of academic curricula for accountants has been highlighted, in order to adjust the training of the latter to the changes which have been taking place in the accounting profession. Regarding the various active learning methods, the main focus here has been on PE, which allows the student to get to know the company by participating in it and applying the theoretical contents acquired in a setting which reproduces the phases of corporate management. The use of ICT for the purposes of this training experience is essential and concerns all aspects of accounting. The latter can avail itself of a corporate IT system where accounting is the pivotal point for all operations. It allows students to gain first-hand knowledge of the tools used in the accounting profession, to share information, data and documents with other students in the course, which results in the development of team-working, problem-solving and decision-making, skills which are strongly recommended by scholars, accountants' associations and operators in the business world. At the same time the management of the company's information system through ICT makes it possible for students to expand their knowledge through analysis and critical assessment of the operations which are implemented, as well as to have a unified vision of the company. This is indeed a distinctive trait of the PE method, which can easily allow for the expression of the effectiveness of ICT use in order to train future accountants.

\section{References}

Albrecht W.S., Sach R.J. (2000), Accounting Education: Charting the Course through a Perilous Future, American Accounting Association, FL

Baharun, R.; Suleiman, E.; Simpol, M. (2006). What employers want from the graduates? Accountants Today, 4, pp. 38-41

Benvenuti U. (2019) “La gestione di un'impresa virtuale e la valutazione delle competenze raggiunte dagli allievi”, Scuola Economia Management e Statistica Università di Bologna, Sede di Forli'. Elaborato finale Corso di Laurea Economia e Management. Relatore Gualdi D.

Bianchi M., Gualdi D., Tampieri L., (2014) The laboratory for enterprise simulation in Forlì and the performance of Perting Ltd 2001-2012 in, Bianchi M., Baseska M., Ngo Mai S., Tampieri L., Verges J. (Eds.) Beyond the Horizon of Tempus Projects. Theory and Practice of Project management, Cesena, Società Editrice Il Ponte Vecchio, Cesena

Bianchi M.(2020) Practice Enterprise and MOOCs in higher education: A possible fusion? EURAM 2020 Dublino Accepted Full Paper

Comoglio M., Cordoso M.A. (1996), Insegnare ad apprendere in gruppo, LAS, Roma pag.6

Elsaadani M.(2015) Information and Comunication Technology Skills' Sufficiency of Egyptian Accounting Graduates, International Journal of Advanced Information Technology (IJAIT) Vol. 5, No. 1/2, April 
Gualdi D., Melagranati F. (2015) Metodologie innovative nell'Accounting Education. La simulazione d'impresa. Indagine sulle motivazioni e aspettative degli studenti universitari di Forlì e Parma. Quaderni del Dipartimento DEM 7/Università degli Studi di Ferrara, Ferrara

Howieson B. (2003) Accounting practice in the new millennium: is accounting education ready to meet the challenge? The British Accounting Review 35 pag. 92

Jebeile, S.; Abeysekera, I. (2010). The spread of ICT innovation in accounting education International Journal of Teaching and Learning in Higher Education, 22(2), pp 158-168

Krishna V.V., (2007) “Universities and emerging national innovation systems," South Asian (Indian) Experience

Osman S.Z.M, Jamaludin R., Mokhtar N.E., (2014) Student Engagement and Achievement in Active Learning Environment among Malaysian Polytechnic Commerce Department. Journal of Education and Literature. Vol. 2, No. 1, , 8-17

Prince M. (2004) Does Active Learning Work? A Review of the Research. Journal of Engineering Education

Rhodes, N. (2013). The Future of Accounting Education with the Integration of ICT. International Conference - The Future of Education, 3rd Edition, Pixel, Florence, Italy, 13-14 June

Veneziani M. (2012), L’Accounting Education : osservazioni preliminari sul caso italiano, Franco Angeli, Milano pag. 50

Veneziani M. (2016) Quale futuro per l'Accounting Education? , Franco Angeli, Milano, pag. 99

Wessesls, P. (2007). An analysis of the current IT education offered to accounting students at South African universities. South African Journal of Accounting Research, 21(1), pp. $103-126$ 